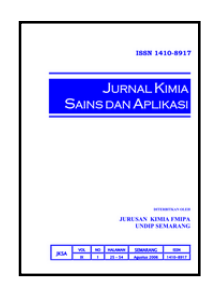

\title{
Sintesis Asam Eugenoksi Asetat (EOA) dari Eugenol untuk Ekstraktan Logam Berat dan Recovery Krom dari Limbah Elektroplating
}

\author{
Muhammad Cholid Djunaidi ${ }^{\mathrm{a}^{*}}$, Khabibi $^{\mathrm{a}}$, Dede Trisna ${ }^{\mathrm{a}}$ \\ a Analytical Chemistry Laboratory, Chemistry Department, Faculty of Sciences and Mathematics, Diponegoro University, Jalan Prof. \\ Soedarto, Tembalang, Semarang 50275 \\ * Corresponding author: choliddjunaidi@live.undip.ac.id
}

\begin{tabular}{l} 
Article Info \\
\hline Keywords: \\
Acid Eugenoxy \\
Acetate (EOA); \\
Eugenol; Heavy \\
Metal Extractants; \\
Recovery \\
Chromium; \\
Electroplating \\
Waste
\end{tabular}

\begin{abstract}
Research on separation of $\mathrm{Cu}(\mathrm{II}), \mathrm{Cd}(\mathrm{II})$ and $\mathrm{Cr}(\mathrm{III})$ and chromium waste recovery have been conducted using the synthesis of Eugenyl oxyacetate carrier. Oxyacetate eugenyl carrier compound was synthesized from eugenol with the addition of $\mathrm{NaOH}$ and chloroacetic acid salt which formed salt then acidified with $\mathrm{HCl}$. After that was purified using diethyl ether and $\mathrm{NaHCO}_{3}$. The synthesis results were analyzed by FTIR and gas chromatography. For the transport process, the bait phase was using a mixture of metal ions $\mathrm{Cu}(\mathrm{II}), \mathrm{Cd}(\mathrm{II})$, and $\mathrm{Cr}(\mathrm{III})$ $50 \mathrm{ppm}$ respectively. The receiver phase was $\mathrm{HCl}$ at $\mathrm{pH} 1$ to 6 . Moreover, to determine the selectivity of compounds EOA, transport processes using a mass variation of eugenyl oxyacetate of 0.3 grams; 0.5 grams and 0.7 grams and blanks were conducted. The best $\mathrm{pH}$ and eugenyl oxyaacetate mass were used for the recovery of chromium metal from electroplating wastes in two ways which with and without reduction of chromium waste. The AAs was used to analyze the amount of transported metal. The test results showed that eugenil oxyacetate was successfully synthesized with $100 \%$ purity. The results of transport indicated that EOA had a high selectivity to $\mathrm{Cr}$ (III) with $95.17 \%$ percent which obtained at the recipient phase at pH 1 and eugenyl oxyacetate mass of 0.7 grams. Results of chromium waste recovery without reduction could transport as much as $5.42 \%$, while the results of chromium recovery with reduction was able to transport waste chromium as much as $68.60 \%$.
\end{abstract}

\section{Abstrak}

Kata kunci: Asam Eugenoksi Asetat (EOA); Eugenol; Ekstraktan Logam Berat; Recovery Krom; Limbah Elektroplating

Telah dilakukan penelitian tentang pemisahan logam $\mathrm{Cu}(\mathrm{II}), \mathrm{Cd}(\mathrm{II})$ dan $\mathrm{Cr}$ (III) dan recovery limbah krom menggunakan senyawa pembawa Eugenil Oksiasetat hasil sintesis. Senyawa pembawa Eugenil oksiasetat disintesis dari eugenol dengan penambahan $\mathrm{NaOH}$ dan asam kloroasetat di mana garam yang terbentuk diasamkan dengan $\mathrm{HCl}$. Setelah itu dilakukan pemurnian dengan dietil eter dan $\mathrm{NaHCO}_{3}$. Hasil sintesis dianalisis dengan FTIR dan kromatografi gas. Untuk proses transport, fasa umpan menggunakan campuran ion logam $\mathrm{Cu}(\mathrm{II}), \mathrm{Cd}(\mathrm{II})$, dan $\mathrm{Cr}(\mathrm{III})$ masing-masing $50 \mathrm{ppm}$, fasa penerima adalah $\mathrm{HCl}$ dengan variasi pH 1 sampai 6. Sedangkan untuk mengetahui selektifitas senyawa EOA dilakukan transport menggunakan variasi massa eugenil oksiasetat yaitu 0,3 gram; 0,5 gram dan 0,7 gram serta blanko. pH dan massa eugenil oksiasetat terbaik digunakan untuk recovery logam krom dari limbah electroplating dengan dua cara yaitu dengan reduksi limbah krom dan tanpa reduksi limbah krom. Untuk mengetahui jumlah logam yang tertransport dianalisis dengan AAS. Hasil yang diuji menunjukkan bahwa eugenil oksiasetat berhasil disintesis dengan kemurnian 100 \%. Hasil transport menunjukkan bahwa EOA memiliki selektivitas tinggi terhadap $\mathrm{Cr}$ (III) dengan persen transport terbaik 95,17 \% yang diperoleh pada $\mathrm{pH}$ fasa penerima 1 dan massa eugenil oksiasetat 0,7 gram. Hasil recovery limbah krom tanpa reduksi mampu mentransport sebanyak 5,42 \%, sedangkan hasil recovery krom dengan reduksi mampu mentransport limbah krom sebanyak $68,60 \%$. 


\section{Pendahuluan}

Eugenol merupakan komponen utama minyak cengkeh dengan kandungan sekitar 80-90\%. Eugenol yang terkandung dalam minyak daun cengkeh, memiliki tiga gugus aktif, yaitu alil, hidroksil, dan metoksi. Dengan tiga gugus aktif tersebut, eugenol berpotensi sebagai senyawa pembawa (carrier), melalui gugus hidroksil, eugenol dapat dimasuki gugus fungsi yang lebih selektif.

Turunan eugenol hasil sintesis dengan atom donor $\mathrm{N}$ yang berasal dari piridil karbinol terbukti selektif terhadap logam borderline $\left(\mathrm{Cu}^{2+}\right)$ [1]. Prinsip kerja dari senyawa pembawa ini didasarkan oleh teori HSAB (pengelompokan asam basa berdasarkan kekerasan dan kelunakan) yang menyatakan bahwa secara umum ionion logam keras (seperti logam alkali, alkali tanah, dan $\mathrm{Cr}^{3+}$ ) lebih kuat kompleksnya dengan atom donor keras (seperti O) dan ion logam lunak (seperti $\mathrm{Cd}^{2+}$ ) akan membentuk kompleks yang lebih kuat dengan atom donor lunak (seperti S) dan ion-ion logam borderline (seperti $\mathrm{Cu}^{2+}$ ) lebih kuat kompleksnya dengan atom donor borderline (seperti N) [2]. Senyawa bergugus aktif atom nitrogen $(\mathrm{N})$ dan atom belerang (S) diharapkan dapat digunakan sebagai senyawa pembawa dalam recovery logam berat, terutama $\mathrm{Cu}^{2+}$ dan $\mathrm{Cd}^{2+}$.

Pada penelitian ini dilakukan recovery ion logam $\mathrm{Cr}^{3+}, \mathrm{Cd}^{2+}$, dan $\mathrm{Cu}^{2+}$. Logam tersebut masing-masing secara berurutan mewakili kelompok dari logam asam keras, lunak, dan borderline (antara keras dan lunak), dari larutan limbah simulasi dengan tiazoetil metil eugenoksi asetat yang disintesis dari eugenol sebagai senyawa pembawa (carrier) menggunakan teknik membran cair ruah BLM (Bulk Liquid Membrane). BLM merupakan tipe membran cair yang paling sederhana dan biasanya dimanfaatkan untuk studi penting untuk memastikan proses transport membran cair.

\section{Metode Penelitian}

\section{Bahan dan Alat}

Eugenol p.a., $\mathrm{Na}_{2} \mathrm{SO}_{4}$ anhidrat teknis, $\mathrm{HCl}$ pekat, $\mathrm{NaHCO}_{3}$ teknis, NaOH p.a, asam kloroasetat teknis, kloroform teknis, dietileter teknis, akuades, garam $\mathrm{CrCl}_{3} \cdot 6 \mathrm{H}_{2} \mathrm{O}$ p.a, garam $\mathrm{CuCl}_{2} \cdot 2 \mathrm{H}_{2} \mathrm{O}$ p.a, garam $\mathrm{CdCl} 2 . \mathrm{H}_{2} \mathrm{O}$ p.a,

Peralatan gelas laboratorium, neraca analisis (Mettler-200), pH meter (HACH E C20), spektrofotometer serapan atom (Perkin Elmer), FT-IR (Nicolete Avatar 360), GC-MS Shimadzu, tabung U.

\section{Sintesis Eugenil oksiasetat (EOA)}

Sebanyak 5 gram eugenol dimasukan ke dalam labu didih ukuran $100 \mathrm{~mL}$, lalu ditambahkan larutan $\mathrm{NaOH}$ $33 \%$ (33 gram $\mathrm{NaOH}$ dalam $100 \mathrm{~mL}$ ) sebanyak 17,5 mL. Selanjutnya campuran diaduk selama kurang lebih 30 menit, dan ditambahkan $12,5 \mathrm{~mL}$ larutan asam kloroasetat 50\% (50 gram dalam $100 \mathrm{~mL}$ air) sedikit demi sedikit dengan pipet tetes sambil terus diaduk. Campuran dipanaskan dalam penangas air dengan suhu $80-90^{\circ} \mathrm{C}$ selama kurang lebih 2 Jam. Campuran didinginkan kemudian diasamkan dengan $\mathrm{HCl} 6 \mathrm{M}$ sampai $\mathrm{pH}$ 1. Disaring, selanjutnya diekstraksi dengan dietil eter sebanyak 3 kali masing-masing $50 \mathrm{~mL}$. Ekstraksi dengan natrium bikarbonat $5 \% \mathrm{~b} / \mathrm{v}$ sebanyak 3 kali masing-masing $30 \mathrm{~mL}$, kemudian lapisan air diasamkan dengan $\mathrm{HCl} 6 \mathrm{M}$ sampai $\mathrm{pH}$ 1. Selanjutnya dilakukan penyaringan, pengeringan dan penimbangan. Senyawa yang diperoleh dianalisis dengan GC-MS dan FT-IR.

\section{Ekstraksi Logam berat dengan EOA.}

Metode recovery yang diterapkan dalam penelitian ini adalah metode pemisahan dengan membran cair ruah (BLM). Eugenol disintesis menjadi eugenil oksiasetat (EOA), hasilnya dianalisis menggunakan kromatografi gas dan FTIR. Eugenil oksiasetat hasil sintesis digunakan sebagai senyawa carrier pada pemisahan ion logam $\mathrm{Cu}(\mathrm{II}), \mathrm{Cd}(\mathrm{II})$ dan $\mathrm{Cr}(\mathrm{III})$, dengan $\mathrm{HCl}$ sebagai fasa penerima. Untuk menentukan $\mathrm{pH}$ fasa penerima terbaik, dilakukan transport pada variasi $\mathrm{pH}$ fasa penerima 1, 2, 3, 4, 5 dan 6 dengan massa eugenil oksiasetat yang dikonstankan sebesar 0,5 gram. Untuk membuktikan efektifitas eugenil oksiasetat dilakukan dengan melakukan transport pada $\mathrm{pH}$ fasa penerima terbaik yang diperoleh pada percobaan sebelumnya dengan memvariasikan massa eugenil oksiasetat yaitu 0,3 gram; 0,5 gram dan 0,7 gram. Dari proses transport dengan limbah simulasi tersebut diperoleh $\mathrm{pH}$ terbaik fasa penerima dan massa eugenil oksiasetat, kemudian dilakukan proses recovery limbah krom dengan menggunakan dua cara yaitu dengan reduksi krom menggunakan pereduksi $\mathrm{NaBH}_{4}$ dan tanpa reduksi. Variabel yang diteliti adalah konsentrasi $\mathrm{H}+$ dalam fasa penerima dan massa senyawa eugenil oksiasetat, dengan lama pengadukan 24 jam, volume fasa umpan dan fasa penerima masing-masing $13 \mathrm{~mL}$.

\section{Hasil dan Pembahasan.}

Sintesis Eugenil oksiasetat (EOA)

Sintesis eugenil oksiasetat ini dilakukan dengan penambahan $\mathrm{NaOH}$ dan asam kloroasetat. Gugus hidroksi pada eugenol dapat bereaksi dengan basa untuk membentuk garam eugenolat. Garam eugenolat ini akan direaksikan dengan asam kloroasetat membentuk eugenil oksiasetat. Reaksi pembentukan eugenil oksiasetat dapat ditunjukkan pada Gambar 1.

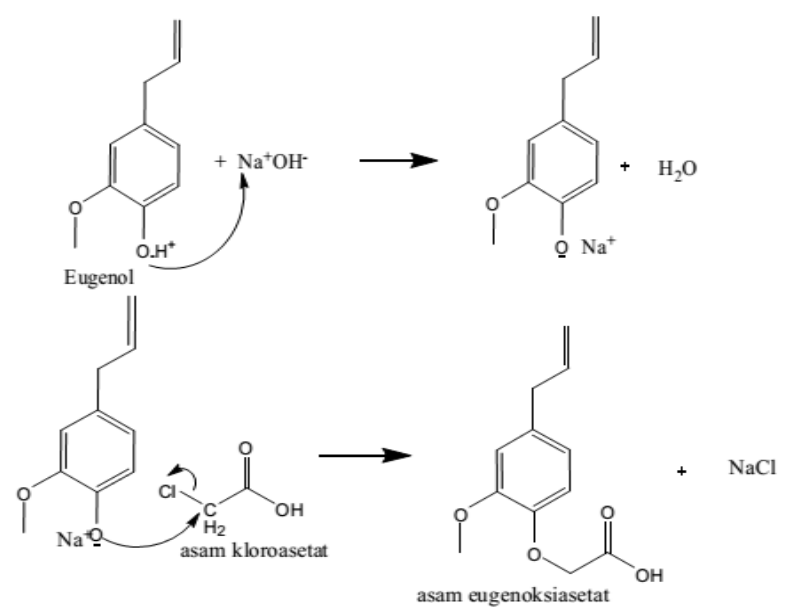


Gambar.1. Reaksi Pembentukan Eugenil oksiasetat [3]

Eugenil oksiasetat yang telah terbentuk dimurnikan dengan menggunakan dietil eter untuk menghilangkan pengotor yang bersifat non polar dan $\mathrm{NaHCO}_{3}$ untuk menghilangkan pengotor yang bersifat polar. Eugenil oksiasetat hasil sintesis berwarna putih kecoklatan, mempunyai sifat larut dalam eter, metanol, dan kloroform dengan titik leleh $91^{\circ} \mathrm{C}$ (Gambar 2).

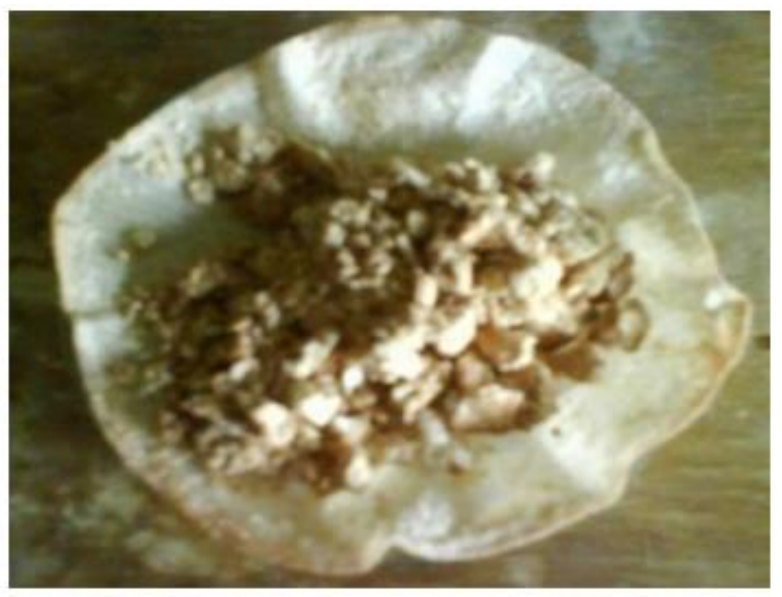

Gambar .2. Eugenil oksiasetat

Hasil pemurnian kemudian dianalisis dengan menggunakan kromatografi gas untuk mengetahui kemurnian eugenil oksiasetat. Pada kromatogram muncul puncak dengan TR 12,293 dengan kemurnian Eugenil oksiasetat sebesar 100\% (Gambar 3).

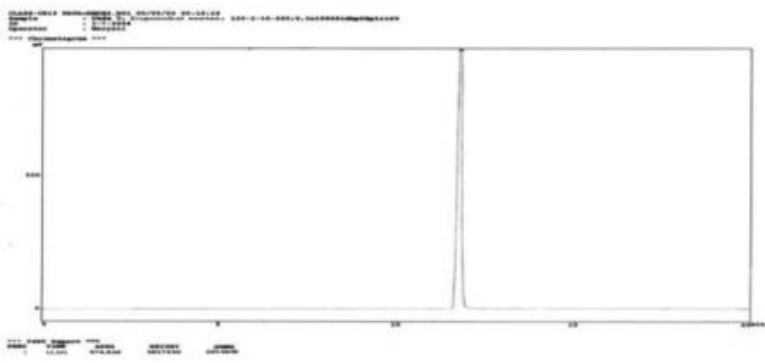

Gambar 3. Spektra GC senyawa Eugenil oksiasetat

Hasil analisis dengan spektrometer inframerah dapat dilihat pada gambar 4 dan tabel 1. Pita serapan pada $3407,94 \mathrm{~cm}^{-1}$ menunjukkan adanya gugus $\mathrm{OH}$. Spektrum senyawa aromatik terlihat pada range 3100$3000 \mathrm{~cm}^{-1}$ yang merupakan pita $\mathrm{C}-\mathrm{H}$ stretching senyawa aromatik, pita serapan sekitar 1650-1500 $\mathrm{cm}^{-1}$ merupakan vibrasi $\mathrm{C}=\mathrm{C}$ dari cincin aromatik dan range $900700 \mathrm{~cm}^{-1}$ menunjukkan bahwa aromatik tersebut tersubstitusi. Serapan pada $1635,88 \mathrm{~cm}^{-1}, 997 \mathrm{~cm}^{-1}$, dan $915,18 \mathrm{~cm}^{-1}$ merupakan serapan gugus vinil ( $\left.\mathrm{RHC}=\mathrm{CH} 2\right)$. Gugus karbonil asam $(\mathrm{C}=\mathrm{O})$ ditunjukkan oleh serapan pada $1727,27 \mathrm{~cm}^{-1}$

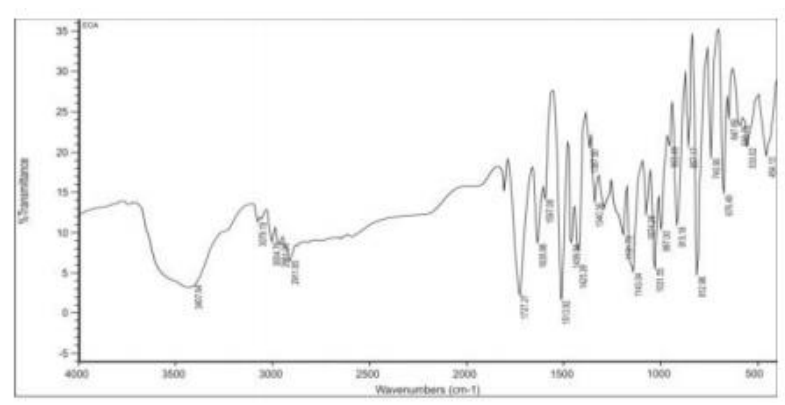

Gambar 4. Spektra FTIR Senyawa EOA

Tabel 1. Data Spektrum FTIR Eugenil oksiasetat

\begin{tabular}{|c|c|c|}
\hline $\begin{array}{c}\text { Gugus } \\
\text { karakteristik }\end{array}$ & Jenis Ikatan & $\begin{array}{c}\text { Serapan } \\
1)\end{array}$ \\
\hline \multirow{3}{*}{$\begin{array}{l}\text { Karbon tak jenuh } \\
\text { rangkap dua }\end{array}$} & $\mathrm{C}=\mathrm{C}$ (stretching) & $1650-1500$ \\
\hline & $\begin{array}{c}\text { Csp2-H } \\
\text { (stretching) }\end{array}$ & $3100-3000$ \\
\hline & $\mathrm{C}=\mathrm{C}$ (bending) & 915,18 \\
\hline \multirow[b]{2}{*}{ Gugus aromatic } & $\mathrm{C}=\mathrm{C}$ (stretching) & $1650-1500$ \\
\hline & $\begin{array}{c}\text { Csp2-H } \\
\text { (stretching) }\end{array}$ & $3100-3000$ \\
\hline $\begin{array}{l}\text { Aromatik } \\
\text { tersubstitusi }\end{array}$ & Ar-R (bending) & $900-700$ \\
\hline $\begin{array}{l}\text { Gugus metilen (- } \\
\text { CH2-) }\end{array}$ & C-C (stretching) & 1459,96 \\
\hline Gugus metil & $\begin{array}{c}\text { Csp3-H } \\
\text { (stretching) }\end{array}$ & $3000-2900$ \\
\hline Gugus Hidroksi & $\mathrm{O}-\mathrm{H}$ & 1367,90 \\
\hline Gugus & (stretching) & 3407,94 \\
\hline karbonil & $\mathrm{C}=\mathrm{O}$ (stretching) & 1727,27 \\
\hline
\end{tabular}

Berdasarkan pita-pita serapan pada spektrum FTIR dapat disimpulkan bahwa senyawa yang dianalisis mengandung inti aromatis tersubstitusi, gugus $\mathrm{OH}$, metilen, metil, vinil, dan karbonil asam.

Jika dibandingkan dengan hasil analisis FTIR senyawa asal yaitu eugenol, maka akan tampak perbedaannya. Dengan data analisis FTIR tersebut, maka dapat disimpulkan bahwa senyawa eugenil oksiasetat telah berhasil disintesis.

\section{Mekanisme Transport Ion Logam dengan Teknik BLM}

Transport ion logam terjadi karena perbedaan kondisi dari dua fasa yaitu fasa umpan yang memiliki tingkat keasaman lebih lemah dan fasa penerima yang memiliki tingkat keasaman lebih kuat dari fasa umpan. Mekanisme transportnya dimulai pada saat terjadi kontak di antarmuka fasa umpan dan fasa membran, senyawa pembawa akan berikatan dengan ion logam untuk membentuk kompleks, selanjutnya kompleks senyawa pembawa akan dibawa ke fasa penerima. Pada fasa ini, senyawa pembawa melepaskan ion logam yang diikatnya dan digantikan dengan $\mathrm{H}+$ untuk selanjutnya ligan bebas terdifusi ke fasa umpan untuk memulai transport kembali [3]. 


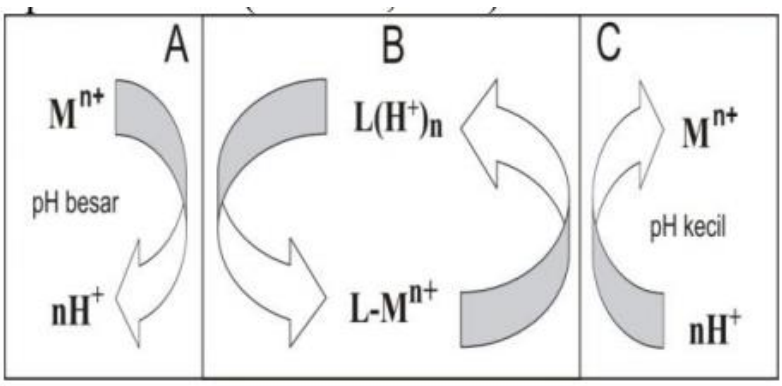

Gambar 5. Mekanisme Pertukaran Kation

$A$ : fase umpan $C$ : fase penerima $M$ : $\operatorname{logam} B$ : fase organik L : pembawa

Oleh karena itu, setelah proses pengadukan selama 24 jam teijadi perubahan $\mathrm{pH}$ pada fasa umpan dan fasa penerima. Penurunan $\mathrm{pH}$ terjadi pada fasa umpan dan kenaikan $\mathrm{pH}$ pada fasa penerima. Hal ini membuktikan bahwa telah terjadi proses pertukaran kation antara ion logam dengan ion $\mathrm{H}+$, seperti dapat dilihat dalam tabel dibawah ini:

Tabel 2. Perubahan pH Pengukuran pada Variasi pH Penerima

\begin{tabular}{cccc}
\hline \multicolumn{2}{c}{ pH Umpan } & \multicolumn{2}{c}{ pH Penerima } \\
\hline Awal & Akhir & Awal & Akhir \\
\hline 6 & 3,26 & 1 & 3,45 \\
6 & 4,06 & 2 & 3,07 \\
6 & 3,54 & 3 & 4,76 \\
6 & 5,43 & 4 & 4,64 \\
6 & 4,74 & 5 & 5,07 \\
6 & 5,58 & 6 & 6,223 \\
\hline
\end{tabular}

Perubahan $\mathrm{pH}$ pada fasa penerima dan fasa umpan di atas menunjukan bahwa $\mathrm{pH}$ berpengaruh terhadap proses transport. Selain dari pengaruh $\mathrm{pH}$ kemampuan transport dapat juga dipengaruhi oleh jenis anion yang berada dalam fasa air, kecepatan pengadukan, dan lainlain [4].

\section{Penentuan pH Fasa Penerima Terbaik (Variasi pH Fasa Penerima)}

Pada penelitian ini dipelajari pengaruh $\mathrm{pH}$ fasa penerima dalam transport logam $\mathrm{Cr}$ (III) dengan teknik BLM. Transport pada membran sangat dipengaruhi oleh keadaan $\mathrm{pH}$, hal ini dikarenakan salah satu pemicu terjadinya transport adalah perbedaan konsentrasi antara fasa umpan dan fasa penerima. Dengan memberlakukan variasi $\mathrm{pH}$ fasa penerima, maka dapat diperoleh $\mathrm{pH}$ fasa penerima terbaik untuk meningkatkan efektivitas transport.

Fasa penerima berisi asam ( $\mathrm{HCl}$ ) sebagai agen pelepas ion logam dari kompleks ligan-logam. Sedangkan pada fasa umpan digunakan campuran tiga jenis logam yaitu, $\mathrm{Cr}(\mathrm{III}), \mathrm{Cu}(\mathrm{II})$ dan $\mathrm{Cd}(\mathrm{II})$ dengan masing-masing konsentrasi $50 \mathrm{ppm}$. Penelitian ini digunakan variasi $\mathrm{pH} \mathrm{HCl}$ yaitu 1, 2, 3, 4, 5 dan 6. Hasil transport selama 24 jam diperoleh persen transport logam dalam fasa penerima

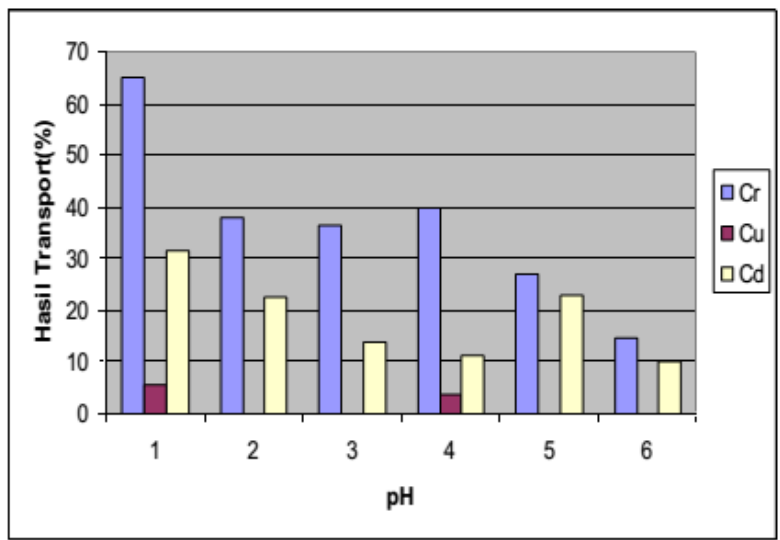

Gambar 6. Diagram Transport Logam Variasi pH

Dari diagram 6 di atas terlihat bahwa urutan selektifitas senyawa adalah $\mathrm{Cr}$ (III), Cd(II) lalu $\mathrm{Cu}$ (II) atau logam keras, lunak dan borderline. Ion logam Cr(III) memiliki persen transport paling besar, hal ini terjadi karena senyawa eugenil oksiasetat mengandung gugus karboksilat, gugus karboksilat termasuk golongan basa keras sehingga akan membentuk kompleks kuat dengan asam keras yaitu ion logam Cr(III). Hal ini sesuai dengan teori HSAB (Hard Soft Acid Base) [2]. Hasil transport yang diperoleh dapat diketahui bahwa ion logam Cd(II) mempunyai persen transport lebih besar dibanding dengan $\mathrm{Cu}(\mathrm{II})$ seperti terlihat pada diagram di atas. Hal ini disebabkan adanya atom-atom donor oksigen netral yang terdapat dalam senyawa eugenil oksiasetat, gugus tersebut akan meningkatkan stabilitas kompleks antara senyawa eugenil oksiasetat yang berfungsi sebagai senyawa pembawa pada membran dengan ion logam Cd(II) [5]. Oleh karena itu ion logam Cd(II) tertransport lebih banyak daripada ion logam $\mathrm{Cu}(\mathrm{II})$.

Pada diagram tersebut juga dapat diketahui bahwa secara umum, semakin asam fasa penerima, maka semakin banyak ion logam yang tertransport di fasa penerima. Makin banyak proton $\left(\mathrm{H}^{+}\right)$di fasa penerima, maka peluang terjadinya pertukaran dengan ion logam akan semakin besar. Hal ini berhubungan dengan mekanisme transport yang terjadi. Transport ion logam berlangsung karena perbedaan kondisi dari dua fasa yang telah dibahas pada sub bab sebelumnya. Untuk $\mathrm{pH}$ terbaik transport diperoleh pada fasa penerima dengan pH 1.

Penentuan Pengaruh Asam Eugenil oksiasetat (Variasi Massa Eugenil oksiasetat

Adanya senyawa pembawa merupakan salah satu faktor penentu keberhasilan transport dengan metode membran cair ruah [6]. Variasi massa senyawa pembawa eugenil oksiasetat bertujuan untuk membuktikan pengaruh senyawa pembawa terhadap keberhasilan transport. Penelitian ini menunjukkan bahwa perubahan massa pada senyawa pembawa dapat mempengaruhi besarnya hasil transport logam. Hal ini didukung dengan adanya data blangko. Pada blangko, transport dilakukan tanpa menggunakan senyawa pembawa. Dari transport tersebut diketahui bahwa jumlah logam yang tertransport sangat kecil 
dibandingkan dengan transport dengan menggunakan senyawa pembawa. Hasil penelitian menunjukkan semakin besar massa senyawa pembawa maka semakin banyak logam yang akan tertransport, terutama untuk ion logam $\mathrm{Cr}$ (III) yang memang memiliki stabilitas kompleks paling besar dibanding ion logam Cd(II) dan $\mathrm{Cu}$ (II). Hal ini membuktikan bahwa semakin besarnya massa senyawa pembawa peluang ion logam untuk berikatan dengan senyawa pembawa tersebut juga semakin besar. Hasil transport campuran logam pada pH 1 dengan variasi massa eugenil oksiasetat diperlihatkan pada Gambar 7 di bawah ini.

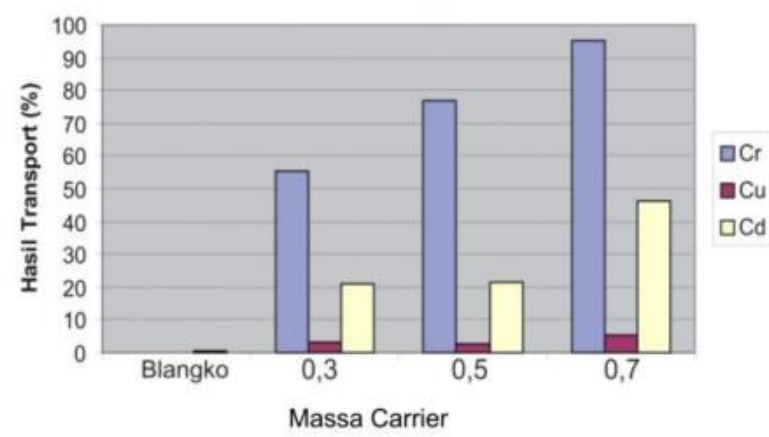

Gambar 7. Grafik Transport Logam dengan Variasi Massa eugenil oksiasetat

Dari grafik 7 di atas dapat diambil kesimpulan bahwa senyawa asam eugenil oksiasetat terbukti berpengaruh terhadap transport ion logam dengan transport maksimal terjadi pada massa asam eugenil oksiasetat sebesar 0,7 gram.

Jika dibandingkan dengan polimernya, dapat diperoleh kesimpulan bahwa monomer asam eugenil oksiasetat memiliki urutan selektifitas yang sama, yaitu $\mathrm{Cr}(\mathrm{III})>\mathrm{Cd}(\mathrm{II})>\mathrm{Cu}(\mathrm{II})$. Sedangkan untuk transport terbaik, monomer eugenil oksiasetat dapat mentransport ion logam $\mathrm{Cr}(\mathrm{III})$ lebih banyak dari polimernya [7]

\section{Recovery Limbah Krom dengan Teknik BLM (Bulk Liquid Membrane) Menggunakan Eugenil oksiasetat sebagai Senyawa Pembawa}

Logam krom biasanya berada pada limbah cair dalam bentuk $\mathrm{HCrO}_{4}, \mathrm{Cr}_{2} \mathrm{O}_{7}{ }^{2-}$ dan $\mathrm{CrO}_{4}{ }^{2-}$. Dalam penelitian ini digunakan dua cara untuk merecovery limbah $\mathrm{Cr}(\mathrm{VI})$ tersebut. Cara pertama adalah dengan transport secara langsung, sedangkan cara yang kedua adalah dengan terlebih dahulu dilakukan penambahan pereduksi $\left(\mathrm{NaBH}_{4}\right.$ dan $\left.\mathrm{HCl}\right)$, lalu kemudian ditransport. Hal ini dikarenakan $\mathrm{Cr}(\mathrm{VI})$ dalam bentuk anion $\mathrm{Cr}_{2} \mathrm{O}_{7}{ }^{2-}$ memiliki muatan negatif. Transport langsung dengan menggunakan senyawa pembawa eugenil oksiasetat kemungkinan tidak akan efektif karena senyawa eugenil oksiasetat tidak memiliki gugus penarik elektron. Sehingga kemudian dilakukan reduksi $\mathrm{Cr}(\mathrm{VI})$ dengan menggunakan $\mathrm{NaBH}_{4}$ dan $\mathrm{HCl}$ sehingga $\mathrm{Cr}(\mathrm{VI})$ tereduksi membentuk $\mathrm{Cr}(\mathrm{III})$ yang bermuatan positif. Reaksi reduksi krom tersebut dijelaskan sebagai berikut.
Senyawa $\mathrm{NaBH}_{4}$ merupakan senyawa pereduksi yang memiliki empat atom hidrida, dengan adanya hidrida tersebut, maka $\mathrm{NaBH}_{4}$ akan mengalami oksidasi. Reaksi oksidasi senyawa $\mathrm{NaBH}_{4}$ tersebut diperkirakan sebagai berikut.

$$
3 \mathrm{BH}_{4}^{-}+6 \mathrm{OH}^{-} \rightarrow 3 \mathrm{BO}_{2}^{-}+9 \mathrm{H}_{2}+6 \mathrm{e}^{-}
$$

Setelah dilakukan reduksi, warna limbah berubah dari warna kuning menjadi kehijauan.

Untuk mengetahui pengaruh pereduksi $\mathrm{NaBH}_{4}$, maka dilakukan analisis dengan menggunakan spektrofotometer UV-Vis, dari analisis tersebut diperoleh spektra limbah yang direduksi dan yang tidak direduksi sebagai berikut.

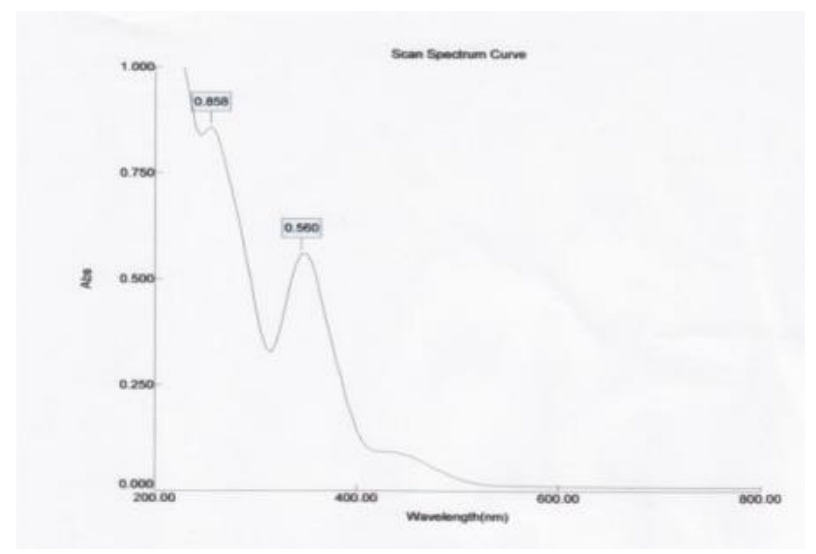

Gambar 8 Spektra UV-Vis Limbah Krom Tanpa Reduksi (Pengenceran 5 kali)

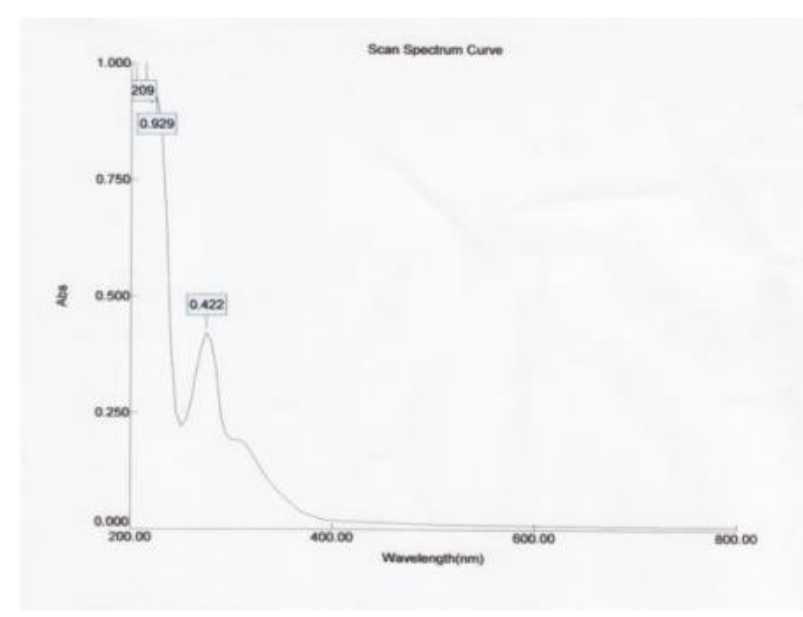

Gambar .9 Spektra UV-Vis Limbah Krom dengan Reduksi $\mathrm{NaBH}_{4}$

Hasil analisis UV-Vis, keberadaan $\mathrm{Cr}(\mathrm{VI})$ ditunjukan dengan adanya peak pada panjang gelombang $345 \mathrm{~nm}$ dan dengan absorbansi 2,8. Sedangkan pada gambar (4.9) juga diperoleh peak pada panjang gelombang 275 $\mathrm{nm}$ dengan absorbansi 0,442. Adanya peak pada panjang gelombang $275 \mathrm{~nm}$ dengan absorbansi 0,442 pada spektra gambar (4.9) adalah sebagai akibat dari reduksi dengan pereduksi $\mathrm{NaBH}_{4}$, yaitu perubahan $\mathrm{Cr}(\mathrm{VI})$ menjadi Cr(III). 
Hasil transport limbah krom dengan penambahan zat pereduksi $\mathrm{NaBH}_{4}$ dan tanpa penambahan zat pereduksi adalah sebagai berikut.

Tabel 3. Hasil Recovery Limbah Krom

\begin{tabular}{cc}
\hline Transport & Hasil recovery \\
\hline Tanpa Pereduksi & $5,42 \%$ \\
Penambahan Pereduksi & $68,60 \%$ \\
\hline
\end{tabular}

Data pada tabel 3 diatas menunjukkan bahwa transport dengan reduksi memiliki hasil transport yang lebih besar dibanding dengan tanpa reduksi. Hal ini dikarenakan senyawa eugenil oksiasetat yang bersifat basa keras akan cenderung berikatan dengan $\mathrm{Cr}$ (III) hasil reduksi yang memiliki sifat asam keras.

Hasil transport ion limbah krom dengan menggunakan pereduksi $\mathrm{NaBH}_{4}$ dan $\mathrm{HCl}$ ternyata lebih sedikit jika dibandingkan dengan transport pada limbah artifisial (95,17\%). Hal ini terjadi karena senyawa $\mathrm{NaBH}_{4}$ tidak dapat mereduksi secara sempurna $\mathrm{Cr}(\mathrm{VI})$ menjadi Cr(III) sehingga jumlah $\mathrm{Cr}$ (III) yang bisa tertransport akan berkurang. Selain itu juga, dimungkinkan adanya pengaruh matriks berupa kation logam lain dalam limbah yang menyebabkan Cr(III) sulit untuk tertransport ke fasa penerima karena terjadinya transport bersaingan.

\section{Kesimpulan}

Eugenil oksiasetat berhasil disintesis dari eugenol. Eugenil oksiasetat (EOA) dapat digunakan sebagai senyawa pembawa (carrier). Senyawa pembawa (carrier) eugenil oksiasetat efektif terhadap transport logam $\mathrm{Cr}$ (III) pada kondisi pH terbaik 1 dan massa eugenil oksiasetat 0,7 gram sebesar 95,17\%. Hasil recovery terbaik limbah krom diperoleh dengan reduksi pada $\mathrm{pH}$ penerima 1 dan massa eugenoksiasetat 0,7 gram sebesar $68,60 \%$.

Saran

Perlu dipelajari lebih lanjut transport logam krom dengan memaksimalkan parameter lain seperti penggunaan asam yang berbeda atau variasi $\mathrm{pH}$ pada fasa umpan. Perlu digunakan pereduktor lain yang lebih efektif dan harganya lebih murah.

\section{Daftar Pustaka.}

[1] Harry Cahyono, Polieugenol Bergugus Aktif N Sebagai Carrier Selektif dan Efektif Bagi Recovery Logam Berat Dengan Teknik Membran Cair, in: Jurusan Kimia, Universitas Diponegoro, Semarang, 2007.

[2] Randall T. Peterson, John D. Lamb, Design of Macrocyclic Carriers for Liquid Membranes, in: Chemical Separations with Liquid Membranes, American Chemical Society, 1996, pp. 130-141.

[3] Theresia Umi Harwati, Sintesis asam poli(Eugenil Oksiasetat) dan studi selektivitasnya terhadap $\mathrm{Cu}(\mathrm{II})$ dalam transport membran cair kloroform, in: Jurusan Kimia, Universitas Gadjah Mada, Yogyakarta, 2002.
[4] B. M. Misra, J. S. Gill, Supported Liquid Membranes in Metal Separations, in: Chemical Separations with Liquid Membranes, American Chemical Society, 1996, pp. 361-375.

[5] Robert D. Hancock, Arthur E. Martell, Ligand design for selective complexation of metal ions in aqueous solution, Chemical Reviews, 89, 8, (1989) 1875-1914 http://dx.doi.org/10.1021/cro0098a011

[6] E. L. Cussler, Rutherford Aris, Abhoyjit Bhown, On the limits of facilitated diffusion, Journal of Membrane Science, 43, 2, (1989) 149-164 http://dx.doi.org/10.1016/S0376-7388(00)85094-2

[7] Aunun Nafisah, Pemisahan $\mathrm{Cu}(\mathrm{II}), \mathrm{Cd}(\mathrm{II})$ dan $\mathrm{Cr}$ (III) dengan Polieugenoksi Asetat Hasil Sintesis, in: Jurusan Kimia, Universitas Diponegoro, Semarang, 2008. 